\title{
HEALTH CONSEQUENCES OF SEX TRAFFICKING: A SYSTEMATIC
} REVIEW

\author{
Simkhada $\mathrm{P}^{1 *}$, Teijlingen van $\mathrm{E}^{2}$, Sharma $\mathrm{A}^{3}$, Bissell $\mathrm{P}^{4}$, Poobalan $\mathrm{A}^{5}$, Wasti $\mathrm{SP}^{6}$ \\ ${ }^{1}$ Public Health Institute, Liverpool John Moores University, Liverpool UK
}

${ }^{2}$ Faculty of Health \& Social Sciences, Bournemouth University, Bournemouth, United Kingdom

\author{
${ }^{3}$ Kalyani, Kathmandu, Nepal \\ ${ }^{4}$ School of Human and Health Sciences, University of Huddersfield, United Kingdom \\ ${ }^{5}$ Institute of Applied Health Sciences, University of Aberdeen, Aberdeen, United Kingdom \\ ${ }^{6}$ Independent Consultant, Green Tara Nepal
}

*Corresponding author:

Prof Padam Simkhada - PhD, Public Health Institute, Liverpool, John Moores University, Henry Cotton Building, 15-21 Webster Street, Liverpool, L3 2ET, UK, Email: P.P.Simkhada@ljmu.ac.uk

\section{ABSTRACT}

Background: Sex trafficking is one of the most common forms of human trafficking globally. It is associated with health, emotional, social, moral and legal problems. The victims of sex trafficking when returned home are often ignored. This study aimed to explore the health consequences of sex trafficking among women and children.

Methods: Medline EMBASE, PsycINFO and CINAHL were systematically searched, from date of inception to July 2016 using a combination of Medical Subject Headings (MeSH) and text words on health risks and consequences of sex trafficking. Electronic searches were supplemented by searching the reference lists of included papers and citation tracking. Both Qualitative and quantitative primary studies published in English and exploring health-related problems among sex trafficked women and children were included in this review. Health outcomes considered were: physical, psychological or social risks and consequences of sex trafficking among women and children. No restrictions were applied to geographical regions as sex trafficking involves victims being trafficked between different countries, and within countries. Data were extracted and study quality independently appraised by two reviewers and narrative synthesis was conducted for this review.

Results: A total of fifteen articles were included covering health risks and well-being related to sex trafficking. Sexual and physical violence among victims such as rape and repetitive stress and physical injuries were common. The prevalence of STI (sexually transmitted infections) and HIV (human immunodeficiency virus) was also reported as high. Being trafficked at a young age, having been in brothels for a longer period and sexual violence and forced prostitution were linked with a higher risk for HIV infection. Physical health problems reported included headaches, fatigue, dizziness, back pain, memory problem, stomach pain, pelvic pain, gynaecological infections, weight loss, lesions or warts, unwanted pregnancies and abortions. The studies on mental health reported that depression, anxiety and post-traumatic stress disorder (PTSD) were commonly reported health consequences among sex trafficking victims. 
Conclusion: there is a compelling need for interventions raising awareness about sex trafficking among young girls and women most at risk of being trafficked. Most studies in this review have focussed on the physical health problems of the trafficked victims although there is also remarkable mental burden amongst those victims. Key policy makers, government officials, public health officials, health care providers, legal authorities and non-governmental organisations (NGOs) should be made aware about the health risks and consequences of trafficking. Trafficking consequences should be recognised as a health issue and all the sectors involved including regulating bodies should collaborate to fight against sex trafficking. Due to the heterogeneity of the articles, no meta-analysis could be conducted.

Keywords: sex trafficking, violence, rape, health consequences

\section{INTRODUCTION}

Human trafficking is broadly defined as "the recruitment, harbouring, transportation, provision or obtaining of a person for labour or services, through the use of force, fraud or coercion for the purpose of subjection to involuntary servitude, peonage, debt bonding, or slavery" According to the United Nations Office on Drugs and Crime (UNODC) sexual exploitation accounts for most $(87 \%)$ of all trafficked victims ${ }^{2}$. Sex trafficking leads victims into severe exploitative conditions generating huge profits for the traffickers ${ }^{3}$. Women and children are the largest groups of victims of sex trafficking according to UNODC $2006 \mathrm{data}^{2}$.

The trafficking of women and children for sexual exploitation not only violates their basic human rights, but both the (a) violence associated with trafficking process and (b) exploitative condition of sex trade have additional adverse effects on victims ${ }^{3,4}$. During the stage of travel and transit in the trafficking process, victims are risk of starvation, drowning and suffocation (due to poor means of transportation), violence and communicable diseases ${ }^{4}$.

The directly observed health consequences of sexual servitude are sexually transmitted infections (STIs), which can create irreversible complications such as infertility, ectopic pregnancy, or in the long run, cervical cancer ${ }^{5}$. The victims often face physical assaults resulting in broken bones, stab wounds, frequent fainting, head injuries, cigarette burns and stress injuries. The commonly reported problems by the sex trafficked victims include general gynaecological problems like chronic pelvic pain, vaginal discharge and pain, pelvic inflammatory disease (PID), unwanted pregnancy and miscarriage. Other commonly occurring physical health symptoms include: headache, fatigue, dizziness, back pain, stomach or abdominal pain, difficulty in remembering ${ }^{6}$. In addition, sex workers are at higher risk of selfmutilation, suicide and homicide ${ }^{7}$. The psychological problems range from anxiety, depression, substance abuse (alcohol and illegal drugs), posttraumatic stress disorder (PTSD), eating disorders ${ }^{7}$, complex mental problems due to forced sex/rape, sexual exploitation and slavery ${ }^{8}$. In short, trafficked persons are abused physically, emotionally and mentally.

Although there are several primary studies conducted on sex trafficking, no systematic review has been conducted to date. Considering the magnitude of the problem this systematic review explores the physical, psychological and social health consequences of sex trafficking among women and children The analysis assesses the associations between consequences of sex trafficking and characteristics of the victims including age, education, socio-economic status, or duration of sexual servitude. 
MATERIALS AND METHODS

\section{Study Design}

This review considered quantitative, qualitative and mixed-methods studies that focussed on health risks and consequences of sex trafficking.

Primary studies published in English and exploring health-related problems among sex trafficked women and children were included in this review. Health outcomes considered were: physical, psychological or social risks and consequences of sex trafficking among women and children. No restrictions were applied to geographical regions as sex trafficking involves victims being trafficked (a) between different countries, and (b) within countries.

\section{Search Strategy}

A robust search strategy was developed using appropriate Medical Subject Headings (MeSH) terms and key words relating to 'sex trafficking', 'women and children' and 'health consequences'. These three blocks were combined using Boolean operators "OR" and "AND" where appropriate. These electronic searches were supplemented by searching the reference lists of included papers and citation tracking. The electronic databases Medline EMBASE, PsycINFO and CINAHL were systematically searched for relevant paper from date of inception to July 2016. The search strategy for Medline was developed and then adapted for other databases. Two authors independently scanned titles and abstracts of all the identified papers. Any discrepancies encountered were resolved by discussion within the team. The potentially eligible articles were selected and full texts were obtained for data extraction. Reference lists of included studies were also cross-checked to identify relevant papers.

\section{Data Extraction}

Two authors independently extracted data using a standard data extraction form that was developed, piloted and modified for the review. Data on study participants, methodology and outcome measures were extracted from the included studies (Table 2). The data extraction form was developed using the Centre for Reviews and Dissemination guidance template ${ }^{9}$, which records basic information first (authors, date, title of paper and journal details), then detailed information about each study i.e. study design, study location, aims of the study, study population, sample size and major findings.

\section{Quality Assessment}

The studies were assessed for their quality using the Critical Appraisal Skills Programme (CASP) checklist. The checklist assesses not only the methodology of the study but also its aims and objective, data collection methods, data analysis, findings, contribution of the study and whether the study is eligible for the review.

\section{Data Synthesis}

Information about study design and sample, definition and method of assessing human trafficking and health problems was summarised. Pooling of the data was deemed inappropriate due to the heterogeneity of the studies. Consequently the results of the review was narratively synthesized and presented by the various health consequences.

\section{RESULTS}

A total of 355 records were identified (Figure 1), and 11 duplicates were removed using reference manager software Mendeley. Screening of the remaining 344 titles and abstracts identified 17 potentially eligible studies. After the critical appraisal of full texts of these papers, 
three papers were excluded due to insufficient information. Following full text screening, 15 papers were included in the review: 14 were from found through electronic database searching and one from reference searching.

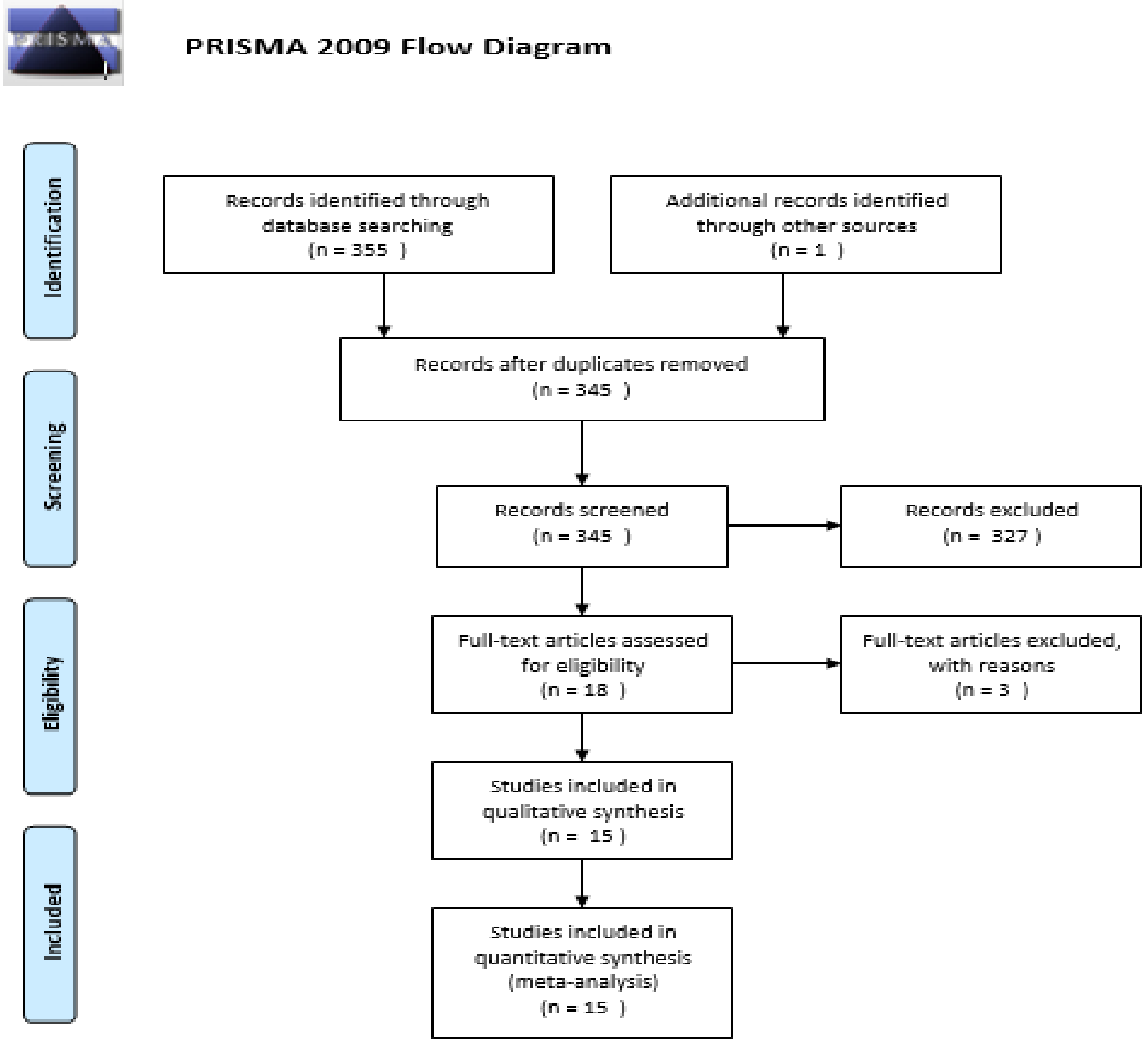

From: Moher D, Lberati A, Tetzlaft J, Altman DG, The PRISMA Group (2009). Preferred Reporting Herns for Systemotic Reviews and Meta

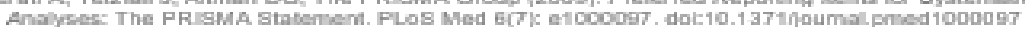

For more information, vislt wurw-prisma-statement.ore.

\section{Figure 1: PRISMA Flowchart for identification and selection of papers}

All studies were conducted between 2004 and 2013 and almost 50\% included studies were conducted in India followed by Nepal. There were eight quantitative studies, two qualitative studies, one mixed-methods study and four case and medical records review papers. Data were collected by using structured and non-structured interviews. Key characteristics of the studies included in this review are presented in Table 1. 
Review Article

Table 1: Description of studies included in this review

\begin{tabular}{|c|c|c|c|c|c|c|}
\hline Author/Year & $\begin{array}{l}\text { Year study } \\
\text { conducted }\end{array}$ & $\begin{array}{l}\text { Location/Settin } \\
\text { g }\end{array}$ & $\begin{array}{l}\text { Study } \\
\text { design }\end{array}$ & $\begin{array}{l}\text { Sample size/ Sampling } \\
\text { method }\end{array}$ & $\begin{array}{l}\text { Mode of } \\
\text { information } \\
\text { collection }\end{array}$ & Outcome measured \\
\hline $\begin{array}{l}\text { Abas et al. } \\
2013\end{array}$ & 2008 & Moldova & $\begin{array}{l}\text { Qualitative } \\
\text { study }\end{array}$ & $\begin{array}{l}120 \text { women } \\
\text { Consecutive sampling }\end{array}$ & Interviews & $\begin{array}{l}\text { - Pattern of trafficking } \\
\text { - Risk factors for mental } \\
\text { disorders }\end{array}$ \\
\hline $\begin{array}{l}\text { Abdulraheem } \\
\text { et al. } 2010\end{array}$ & 2008 & Nigeria & $\begin{array}{l}\text { Mixed- } \\
\text { methods }\end{array}$ & $\begin{array}{l}\text { For Quantitative }=\quad 462 \\
\text { women and } 100 \text { children } \\
\text { Multistage cluster sampling }\end{array}$ & $\begin{array}{l}\text { Questionnaires } \\
\text { survey, } \\
\text { interviews and } \\
\text { FGDs }\end{array}$ & $\begin{array}{l}\text { - Health and social problems of } \\
\text { trafficking }\end{array}$ \\
\hline $\begin{array}{l}\text { Decker et al. } \\
2012\end{array}$ & 2007 & Thailand & $\begin{array}{l}\text { Secondary } \\
\text { quantitative } \\
\text { data analysis }\end{array}$ & 815 participants & $\begin{array}{l}\text { Secondary data } \\
\text { analysis }\end{array}$ & $\begin{array}{l}\text { - Experiences of sexual risk } \\
\text { and sexual and reproductive } \\
\text { health outcomes }\end{array}$ \\
\hline $\begin{array}{l}\text { Dharmadhika } \\
\text { ri et al. } 2009\end{array}$ & 2005 & Nepal & $\begin{array}{l}\text { Quantitative } \\
\text { study }\end{array}$ & 287 women & $\begin{array}{l}\text { Case records } \\
\text { reviewed }\end{array}$ & $\begin{array}{l}\text { - Who are sex trafficked, the } \\
\text { high prevalence of HIV and } \\
\text { the risk of transmission of TB } \\
\text { from and to others. }\end{array}$ \\
\hline $\begin{array}{l}\text { George et al. } \\
2013\end{array}$ & 2010 & India & $\begin{array}{l}\text { Cross- } \\
\text { sectional } \\
\text { quantitative } \\
\text { study }\end{array}$ & $\begin{array}{l}1137 \text { female sex workers } \\
\text { (FSW) }\end{array}$ & $\begin{array}{l}\text { Questionnaire } \\
\text { survey }\end{array}$ & $\begin{array}{l}\text { - Prevalence of sex trafficking } \\
\text { as mode of entry into sex } \\
\text { work } \\
\text { - associations between sex } \\
\text { trafficking and HIV risk }\end{array}$ \\
\hline
\end{tabular}


Review Article

- recent violence experience, symptoms of sexual ill health

\begin{tabular}{|c|c|c|c|c|c|c|}
\hline $\begin{array}{l}\text { Gupta et al. } \\
2009\end{array}$ & 2006 & India & $\begin{array}{l}\text { Qualitative } \\
\text { analysis }\end{array}$ & $\begin{array}{l}61 \text { repatriated women and } \\
\text { girls in an NGO }\end{array}$ & $\begin{array}{l}\text { Case narratives } \\
\text { reviewed }\end{array}$ & $\begin{array}{l}\text { - Potential mechanisms of HIV } \\
\text { infection }\end{array}$ \\
\hline $\begin{array}{l}\text { Gupta et al. } \\
2011\end{array}$ & 2006 & India & $\begin{array}{l}\text { Cross- } \\
\text { sectional } \\
\text { quantitative } \\
\text { study }\end{array}$ & $\begin{array}{l}812 \text { FSWs } \\
\text { Respondent-driven sampling }\end{array}$ & $\begin{array}{l}\text { Questionnaire } \\
\text { survey }\end{array}$ & $\begin{array}{l}\text { - prevalence of sex trafficking } \\
\text { as a mode of entry into sex } \\
\text { work } \\
\text { - associations between sex } \\
\text { trafficking and recent } \\
\text { violence experiences } \\
\text { - HIV vulnerability }\end{array}$ \\
\hline $\begin{array}{l}\text { Oram et al. } \\
2012\end{array}$ & 2008 & Moldova & $\begin{array}{l}\text { Qualitative } \\
\text { study }\end{array}$ & $\begin{array}{l}120 \text { women } \\
\text { Consecutive sampling }\end{array}$ & Interviews & - Physical health symptoms \\
\hline $\begin{array}{l}\text { Sarkar et al. } \\
2008\end{array}$ & Not stated & India & $\begin{array}{l}\text { Cross- } \\
\text { sectional } \\
\text { quantitative } \\
\text { study }\end{array}$ & 580 sex workers & $\begin{array}{l}\text { Questionnaire } \\
\text { survey }\end{array}$ & $\begin{array}{l}\text { - understand sex- trafficking, } \\
\text { violence, negotiating skills, } \\
\text { and HIV }\end{array}$ \\
\hline $\begin{array}{l}\text { Silverman et } \\
\text { al. } 2006\end{array}$ & 2005 & India & $\begin{array}{l}\text { Quantitative } \\
\text { study }\end{array}$ & $\begin{array}{l}175 \text { sex-trafficked women } \\
\text { and girls }\end{array}$ & $\begin{array}{l}\text { Case records and } \\
\text { HIV test results }\end{array}$ & $\begin{array}{l}\text { - prevalence \& predictors of } \\
\text { HIV }\end{array}$ \\
\hline $\begin{array}{l}\text { Silverman et } \\
\text { al. } 2007\end{array}$ & 2006 & Nepal & $\begin{array}{l}\text { Medical and } \\
\text { case records } \\
\text { review }\end{array}$ & $\begin{array}{l}287 \text { repatriated girls and } \\
\text { women reporting being } \\
\text { trafficked at an NGO }\end{array}$ & $\begin{array}{l}\text { Secondary data } \\
\text { analysis }\end{array}$ & 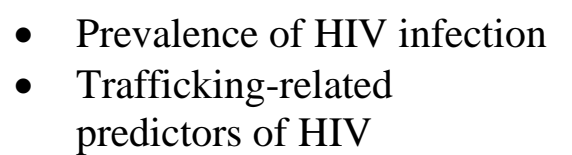 \\
\hline
\end{tabular}




\section{Review Article}

\begin{tabular}{|c|c|c|c|c|c|c|}
\hline $\begin{array}{l}\text { Silverman et } \\
\text { al. } 2011\end{array}$ & Not stated & India & $\begin{array}{l}\text { Quantitative } \\
\text { study }\end{array}$ & $211 \mathrm{FSW}$ & $\begin{array}{l}\text { Questionnaire } \\
\text { survey }\end{array}$ & $\begin{array}{l}\text { - Prevalence of trafficking } \\
\text { among HIV-infected FSWs } \\
\text { - Association with sexual } \\
\text { violence, sexual risk, and } \\
\text { alcohol use }\end{array}$ \\
\hline $\begin{array}{l}\text { Tsutsumi et al. } \\
2008\end{array}$ & 2005 & Nepal & $\begin{array}{l}\text { Cross- } \\
\text { sectional } \\
\text { quantitative } \\
\text { study }\end{array}$ & 162 trafficking survivors & $\begin{array}{l}\text { Questionnaire } \\
\text { survey }\end{array}$ & $\begin{array}{l}\text { - } \begin{array}{l}\text { mental health status } \\
\text { including } \\
\text { depression, PTSD }\end{array} \\
\text { anxiety, }\end{array}$ \\
\hline $\begin{array}{l}\text { Wirth et al. } \\
2012\end{array}$ & Not stated & India & $\begin{array}{l}\text { Quantitative } \\
\text { study }\end{array}$ & 1814 & $\begin{array}{l}\text { Case and } \\
\text { Medical records } \\
\text { review }\end{array}$ & $\begin{array}{l}\text { - Association between sex } \\
\text { trafficking and HIV }\end{array}$ \\
\hline $\begin{array}{l}\text { Zimmerman } \\
\text { et al. } 2008\end{array}$ & 2004-2005 & $\begin{array}{l}\text { Belgium, } \\
\text { Bulgaria, Czech } \\
\text { Republic, Italy, } \\
\text { Moldova, } \\
\text { Ukraine \& UK }\end{array}$ & $\begin{array}{l}\text { Quantitative } \\
\text { study }\end{array}$ & $\begin{array}{l}\text { Consecutive sampling of } \\
192 \text { eligible women and girls } \\
\text { who access post trafficking } \\
\text { assistance provided by } \\
\text { I/NGOs }\end{array}$ & $\begin{array}{l}\text { Semi-structured } \\
\text { questionnaire } \\
\text { survey }\end{array}$ & - Health of trafficked women \\
\hline
\end{tabular}




\section{Results of the Review}

The evidence from the studies is presented under three broad categories: (a) human trafficking profile; (b) physical health outcomes; and (c) mental health outcomes

\section{a. Human trafficking profile}

Ten studies included in this review provided a profile of human trafficking ${ }^{4,10-19}$. The ages of the trafficked victims ranged from 11 to 44 years ${ }^{4,10,11,13-19}$. The duration of trafficking ranged from 9.6 to 54.3 months ${ }^{10,14,19}$. Five studies reported on awareness education, whereby most of the trafficked victims were not aware about trafficking and the prevalence of HIV and most had low education levels ${ }^{4,12,13,16,19}$. One study stated that many sexually abused trafficked women did not seek help due to their lack of awareness of what constitutes sexual violence, ignorance of trafficking crimes and self-blame and stigma ${ }^{12}$. Three studies reported on traffickers, the most traffickers were strangers closely followed by friends, intimate partners, family members and acquaintances ${ }^{4,9,10,15}$. In one study the perpetrators of trafficked women were reported to be educated and 'enlightened' people ${ }^{14}$. The factors that contributed to trafficking were reported as poverty ${ }^{4,17}$, lack of parental guidance, parental discrimination against a girl child, cultural practices and attitudes, lack of knowledge of human trafficking, family disintegration, martial disharmony, domestic violence, school dropout, lack of government's monitoring of trade and working environments ${ }^{4}$. Five studies reported the tactics used to lure women into trafficking as economic opportunities, promise of good accommodation, visiting a relative or religious event, drugging and kidnapping, marriage proposals and brute force ${ }^{4,10,11,17,18}$.

\section{b. Physical health outcomes}

Thirteen studies in our review reported on physical health outcomes $4,9-12,14-17,19-22$. Six out the thirteen studies reported on HIV prevalence among sex trafficking victims 10,11,17,18,22,23. The prevalence of HIV was found relatively high for sex trafficking victims 11,17,18,22. Being trafficked at an early age ${ }^{10,17,23}$, having spent longer in brothels ${ }^{22}$, sexual violence ${ }^{23}$ and forced prostitution were linked with a higher risk of HIV infection. Further factors resulting in higher risk of HIV infection were a lack of autonomy that lead to use of rape as coercing initiation into sex work, inability to refuse sex, inability to negotiate condom use, substance abuse as a coping strategy and inadequate access to healthcare ${ }^{10-11}$. One study reported that tuberculosis was common among sex trafficked victims, and $88 \%$ of those infected with tuberculosis were HIV co-infected ${ }^{20}$. Five studies mentioned sexual and physical violence among victims including constant rapes and repetitive stress and physical injuries $4,12,17,18,23$. Other physical health outcomes reported were headaches, fatigue due inadequate rest, dizziness, back pain memory problem, stomach pain, pelvic pain, gynaecological infections, weight loss, lesions or warts, pregnancy and abortion and the most common of all were STIs 4,11-13,16. Sex trafficking victims reported substance abuse as a coping mechanism or a way to lose inhibitions, the drugs were commonly paid for by the clients ${ }^{11,15,17}$.

\section{c. Mental health outcomes}

Four studies reported on mental health outcomes ${ }^{4,12,14,19}$. The studies discussing the mental health outcomes of the victims of trafficking reported that depression, anxiety and PTSD were the most commonly occurring conditions ${ }^{4,12,14,19}$. Almost all $(83.6 \%)$ of victims reported that they suffered from depression at some point ${ }^{4,14,19}$. Other behavioural problems encountered were hostility, aggression, social withdrawal, altered behaviour in front of men and no any motivation to see them ${ }^{4,12,14,19}$. 
Table 2: Key Findings of the Review

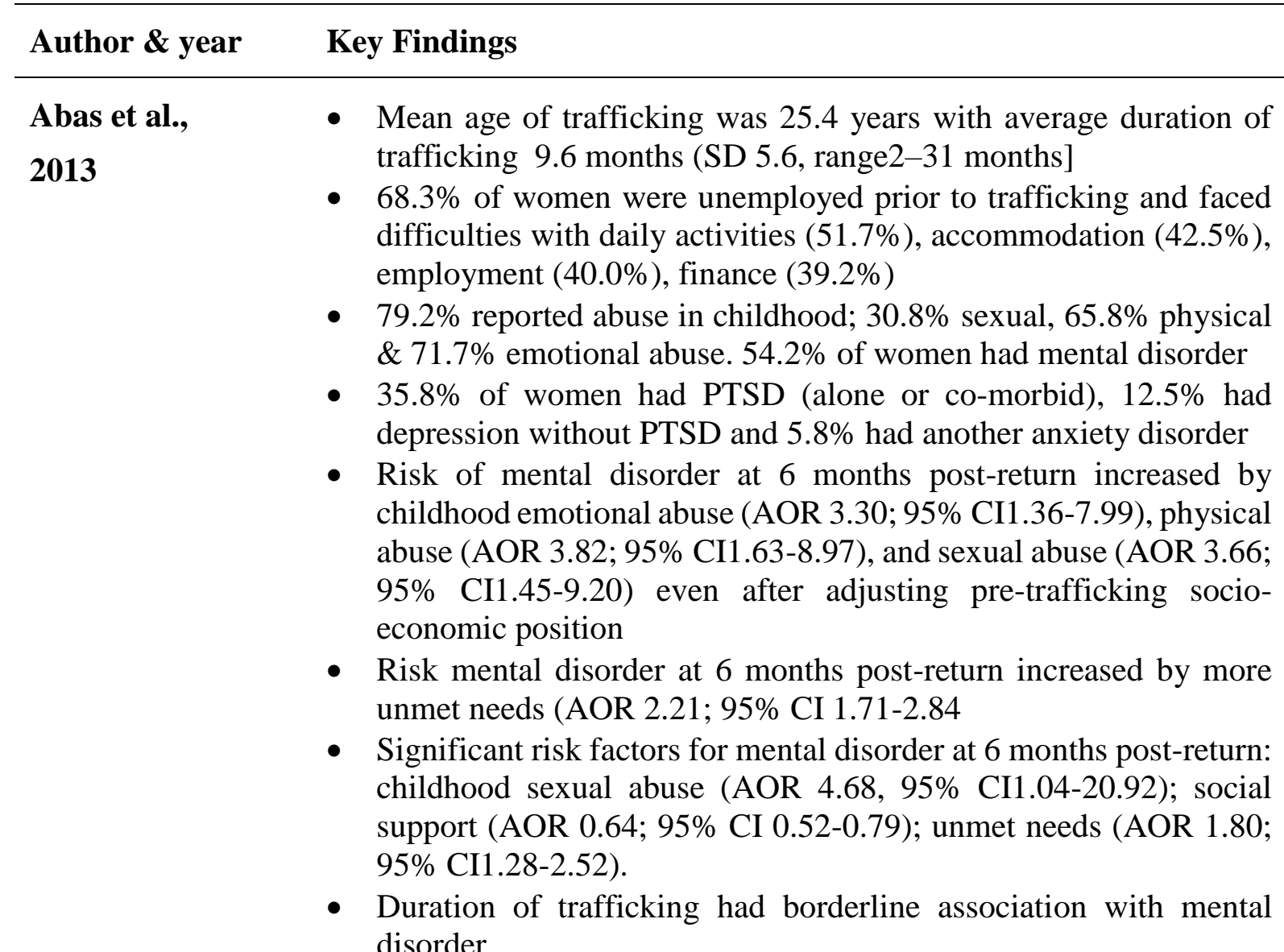

\begin{abstract}
Abdulraheem Oladipo 2010
\end{abstract}

Decker et al., 2011
\& - Mean age of trafficked women 18.6 years \& 14.2 among children

- $46.7 \%$ trafficked for commercial sex \& $4.3 \%$ for sale to brothel

Influencing factors for trafficking:

- Poverty (58.7\%), lack of parental education (60.4\%), parental discrimination favouring boys over girls $(51.4 \%)$, cultural practices / traditional attitudes (35.6\%), lack of knowledge of trafficking (33.6\%), family disintegration (21.5\%), family disharmony (32.6\%), family in debt $(7.3 \%)$, marital disharmony $(15.8 \%)$ and domestic violence $(14.2 \%)$

Social \& health problems are lack of access to birth control (90.6\%), constant rape $(80.8 \%)$, forced abortions \& contraceptive use $(79.5 \%)$, STIs $(68.9 \%)$, repetitive stress injuries $(75.4 \%)$, inadequate rest $(66.4 \%)$, psychological abuse (90.5\%), depression $(83.6 \%)$, emotional trauma $(72.4 \%) \&$ sexual abuse in children $(70 \%)$

- Trafficked FSWs more likely to report anal sex in month prior to survey $(8.2 \%$ vs. $2.6 \%, \mathrm{p}=0.006)$; adjusted analyses indicated a non-significant trend towards elevated risk (ARR 2.26, 95\% CI $0.96,5.31)$. 
- Trafficking was associated with recent condom failure $(22.4 \%$ vs. $12.4 \%$, ARR $1.80,95 \%$ CI $1.15,2.80) \&$ condom non-use $(8.2 \%$ vs. $3.1 \%$, ARR $3.35,95 \%$ CI 1.49, 7.52).

- Lifetime experience of client condom refusal was prevalent $(71.5 \%)$

- Compared to non-trafficked counterparts, sex trafficked FSWs were more than twice as likely to have experienced sexual violence at initiation to sex work (ARR 2.29, 95\% CI 1.11, 4.72).

- $\quad 36.6 \%$ experienced recent workplace mistreatment, those entering via sex trafficking were almost twice as likely (ARR 1.38, 95\% CI $1.13,1.67)$.

- Having worked in multiple locations was more common among trafficked FSWs (69.4\% vs. 41.2\%, ARR 1.44, 95\% CI 1.24, 1.68).

- Trafficked FSWs were slightly more likely to report low levels of HIV knowledge than non-trafficked counterparts $(38.8 \%$ vs. $27.4 \%$ ); adjusted analyses indicated a non-significant trend towards elevated risk for limited HIV knowledge (ARR 1.13, 95\% CI 0.92, 1.37).

- $67.3 \%$ ever been tested for STI and $83 \%$ for HIV; no variation based on sex trafficking.

- Trafficked FSWs three times more likely to have become pregnant since entering sex work (ARR 3.09, 95\% CI 1.93, 4.95)

- FSWs more likely to report abortion during sex work; $11.8 \%$ of trafficked FSWs vs $4.7 \%$ of non-trafficked women (ARR 2.83, $95 \%$ CI 1.48, 5.39).

- STI symptoms in 4 months prior to survey reported by $65.5 \%$.

- A trend toward elevated risk for lesions or warts among trafficking victims was detected (17.9\% vs. $11.8 \%$, ARR 1.57, 95\% CI 1.00, 2.45).

Dharmadhikari et al., 2009

George et al., 2013
- 17 TB cases were found out of 287 screened (5.9\%), with $70 \%$ developing after release from forced sexual servitude.

- $88 \%(15 / 17)$ of TB cases were HIV co-infected.

- Overall, 35.3\% women were younger than 18 at entry into sex work, of remaining $64.7 \%$ over $18,23.5 \%$ forced or lured into sex work

- trafficked FSWs tended to be younger, involved in sex work for longer, unmarried; have a partner, no children, fewer dependants; savings, had sex work contract in past 6 months, listed sex work as only source of work

- $61 \%$ FSWs were at risk of HIV, having confirmed at least 1 of 4 indicators

- Women who were trafficked had a higher HIV risk compared with non-trafficked FSWs

- They were more likely to have sex with more than 10 person and engage in sex work 4 days and above per week 
- $53 \%$ FSWs reported physical violence and 76.6\% sexual violence in past six months.

- Trafficked FSWs were more likely than other FSWs to have an increased risk of sexual, physical, sexual violence

- $49 \%$ FSWs reported 1 or more symptoms of sexual ill health in past 6 months.

Gupta et al., 2009

\section{Gupta et al.,} 2011

Oram et al., 2012
- Mean age at trafficking was 17 years and 57.4\% were trafficked under false economic pretence

- None were told they were going for sex work and rape was a tool for initiation into sex work

- Chronic sexual violence, substance use and inability to refuse sex

- Inability to access healthcare

- $\quad 78.7 \%$ tested for HIV among these $45.8 \%$ were found to be HIV positive

- Women entering via sex trafficking almost twice as likely as other FSWs to report any form of violence (53.5\% versus $39.1 \%$; adjusted odds ratio [AOR], 1.93; 95\% [CI], 1.32-2.81); physical or sexual violence $(53.5 \%$ versus $38.4 \%$; AOR, 1.99 ; $95 \%$ CI, $1.36-$ $2.90)$; and threats of severe violence $(11.5 \%$ versus $6.1 \%$; AOR; 1.85 ; 95\% CI, 0.99-3.50).

- FSWs who had entered via trafficking were more likely than other FSWs to report having sex with 10 and above $(41.0 \%$ versus 27.0\%; AOR, 1.63; 95\% CI, 1.11-2.41), engaging in sex work for 4 or more days $(71.2 \%$ versus $53.3 \%$; AOR, 1.76 ; $95 \%$ CI, 1.18 2.63), less likely to use FSW-targeted services in last 6 months (44.6\% versus $59.1 \%$; AOR, 0.60; 95\% CI, 0.42-0.86).

- Higher consistent condom use was observed among trafficked FSWs, (50.0\% versus 37.9\%), but not significant (AOR, 1.20; 95\% CI, 0.88-1.92) observed and no significant differences in HIV knowledge were observed.

- Mean age of women was 25.4 years and $67.5 \%$ were exploited for longer than six months, with $27.5 \%$ trafficked for longer than a year

- $88.2 \%$ of the victims had completed at least compulsory lower secondary education, $68 \%$ had been unemployed prior to being trafficked.

- $54.2 \%$ reported having experienced either sexual abuse or severe physical abuse as children.

- Only $3.3 \%$ of women reported being free of symptoms in past 2 weeks.

- $65 \%$ of women suffered from between 1 and 5 symptoms concurrently

- $29 \%$ reported suffering from 6 or more symptoms concurrently 
- Women reported headaches $(61.7 \%)$, stomach pain $(60.9 \%)$, memory problems (44.2\%), back pain (42.5\%), loss of appetite (35\%), tooth ache $(35 \%)$.

- Duration of exploitation, was strongly associated with prevalence of headache (OR 1.18, 95\% CI1.08-1.30, p<0.001) memory problems (OR 1.09, 95\% CI 1.02-1.17, $\mathrm{p}=0.012$ ).

- Borderline results in respect of stomach pain (OR 1.06, 95\% CI0.99-1.30, $\mathrm{p}=0.122$ ), back pain (OR 1.05, 95\% CI0.98-1.12, $\mathrm{p}$ $=0.165)$.

- Sex-trafficked women reported higher prevalence of headache (65.0\% vs. $47.8 \%, p=0.133)$ than labour-trafficked women.

- Labour-trafficked women had more back pain $(38.1 \%$ vs. $60.9 \%, p$ $=0.052$ ).

- Sex-trafficked women reported higher prevalence of gynaecological problems (16.5\% vs. $0 \%)$, weight loss $(28.9 \%$ vs. $13.0 \%$ ) than labour-trafficked women, latter reported higher prevalence of vision problems (21.7\% vs. $10.3 \%)$.

Sarkar et al., 2008

Silverman et al., 2006
- Mean age was 29.8 years and duration of sex work was 8.6 years.

- $46 \%$ of the participants started sex work between age 16-20; $25 \%$ by age of $21-25 ; 10 \%$ initiated sex work at 15 years or below

- $58 \%$ entertained 1-2 client(s) daily, followed by 3-4 clients (34\%). Only $1 \%$ entertained seven or more clients, whereas the remaining $7 \%$ entertained 5-6 clients daily

- $68 \%(\mathrm{n}=397)$ sex workers joined profession voluntarily \& primarily due to poverty

- About 24\% were cheated and forced to become sex worker against their will where as $8 \%$ were forced to join directly or indirectly by family

- Trafficked FSWs faced more violence

- $63 \%$ sex workers who faced violence $(n=166)$ in early sex work were victims of trafficking; $15 \%$ faced physical, $55 \%$ sexual violence, $30 \%$ both.

- About 29\% sex workers faced violence early on in their career

- HIV was $23 \%(n=32)$ among sex workers who faced sexual violence initially compared to $8 \%(n=36)$ among those who did not.

- Most $(55 \%)$ consumed alcohol; of those $73 \%$ consumed it in varying quantity, frequency before entertaining clients.

- $\quad \mathrm{HIV}$ associated with age $\leq 20(\mathrm{OR}=2.6$; CI 1.2-5.6), trafficking $(\mathrm{OR}=1.9$; CI 1.1-3.3), violence faced during early phase $(\mathrm{OR}=2.6)$, sexual violence $(\mathrm{OR}=3.2$; $\mathrm{CI} 1.8-5.7)$, and forced sex $(\mathrm{OR}=3.0 ; \mathrm{CI}$ 1.6-5.5)

- Mean age of women at trafficking was 16.8 years, mean time served in brothels at rescue was 15.8 months, with $69.3 \%$ serving in brothels for 1 year or less and $40.9 \%$ reporting brothel confinement 
for 6 months. Young age at trafficking was associated with longer brothel duration.

- $65.9 \%$ of rescued women were trafficked to brothels at age 18

- $22.9 \%$ rescued sex-trafficked women and girls tested positive for HIV

- Mean age at trafficking was younger for HIV-positive (15.9 years) as compared to HIV-negative women and girls (17.2 years; $\mathrm{P}=$ $0.06)$.

- Those HIV positive in brothels longer; mean brothel stay for those tested positive was 27.6 months \& 11.6 months tested negative $(\mathrm{P}$ - 0.001).

- Brothel duration predictor HIV status in models adjusted for age at trafficking $(\mathrm{OR}=1.04,95 \% \mathrm{CI}$ : 1.01-1.06), among Indian trafficking victims, age at trafficking/Indian state of origin $(\mathrm{OR}=$ 1.03, 95\% CI: 1.00-1.07) 3-4\% increased risk of HIV for each extra month in brothel.

- Girls trafficked $\leq 18$ years had significantly longer periods in brothel (mean 18.5 months) than those trafficked $18+($ mean $=9.6$ months; $\mathrm{P}=0.007)$.

Silverman et al., - Mean age of trafficked women was 15.9 years and mean time 2007 served in brothel was 25.8 months

- Tactics used by traffickers; inviting women to accompanying them for benign purposes (23.6\%), drugging \& kidnapping (16.4\%) and false promises of marriage $(7.1 \%)$

- $46.2 \%$ trafficked by strangers, $29.3 \%$ friends, $12 \%$ partners, $8.9 \%$ by relatives

- $43 \%$ trafficked victims under 15 years were prostituted in multiple brothels

- $13.2 \%$ trafficked victims at age $18+$ prostituted in multiple brothels

- Girls $\leq 14$ more likely to be detained in more than one brothel (OR, 2.67; $95 \%$ CI, 1.12-6.33)

- Increased risk HIV in those trafficked $\leq 14$ vs $>18$ years (OR, 3.42; 95\% CI, 1.51-7.75)

- Marginal increase in risk of HIV with duration of brothel servitude (OR, 1.02; 95\% CI, 1.01-1.04), for every additional month

- Multiple brothels vs single one increased HIV risk (OR, 2.02; 95\% CI, 1.00-4.09), but wide CI

- Increased risk of HIV in Mumbai vs other destinations (OR, 6.27; 95\% CI, 3.04-12.90).

Silverman et al., - Median age of trafficked women was 30 year and violence and 2011 sexual risk exposures highly prevalent during first month in sex work

- Volume of male clients first month was high; 35.9\% had sex with 17 clients per day 
- $\quad 41.7 \%$ HIV-infected FSWs reported being forced or coerced (i.e. trafficked) into sex work

- Common perpetrators were co-workers (25.0\%), acquaintances $(25.0 \%)$, strangers $(18.2 \%)$, family $(9.1 \%) .50 .2 \%$ entered sex work before age 18

- $62 \%$ of HIV-infected FSWs reported sexual violence from male clients during the initial month after entry

- $50.7 \%$ HIV-infected FSWs reported no use of condoms in their first month in sex work

- $54 \%$ reported frequent alcohol use in month after entry; $59.2 \%$ used alcohol at first sex work episode

- Those trafficked into sex work had significantly higher odds of sexual violence in initial month (AOR 3.1; 95\% CI, 1.6-6.1), high volume of male clients (AOR, 3.3; 95\% CI, 1.8-6.1), no use of condoms in same period (AOR, 3.8; 95\% CI, 2.1-7.1)

- HIV-infected FSWs who entered sex work involuntarily had significantly higher odds of frequent alcohol use during their first month of sex work (AOR, 1.9; 95\% CI, 1.0-3.4) alcohol use at their first sex work episode (AOR, 2.2; 95\% CI, 1.2-4.0)

Tsutsumi et al., - Mean age of sex workers (range 11-38 years) was significantly 2008

Wirth et al., 2013 higher than non-sex workers group (range 15-44 years) $(\mathrm{p}<0.01)$

- Mean duration of being trafficked was 29.7 months (range 2-144 mths) in sex workers \& 54.3 (range 1-168 months) in non-sex workers $(\mathrm{p}<0.01)$.

- Sex workers perceived their social and economic status to be worse than non-sex workers did $(\mathrm{p}<0.01)$

- Prevalence of HIV higher in sex workers ( $\mathrm{p}<0.01$ ); (29.6\%) were infected compared to none in non-sex workers.

- FSWs trafficked at older age were at higher risk (mean 16.6 vs 11.73) $(\mathrm{p}<0.01)$

- $30.0 \%$ non-sex workers group trafficked by immediate family ( $\mathrm{p}$ $<0.05)$

- Sex workers were above depression cut-off point, compared to $80.8 \%$ of non-sex workers ( $\mathrm{p}<0.01$ )

- More (29.6\%) sex workers screened positively for PTSD symptoms in past month than the non-sex workers group $(7.5 \%)(\mathrm{p}<0.01)$

- Women started sex work on average at $24 ; 16 \%$ started sex work before age $18 ; 15 \%$ were forcibly prostituted; $0.7 \%$ started young $\&$ were forced

- Forcibly prostituted women more likely to be separated/ deserted by husbands; have worked in brothel \& experienced sexual violence in past year

- Women entering sex trade younger were more likely to be unmarried, have more clients per week but charged less per sexual encounter 
- In unadjusted analyses, forced prostitution was associated with a nearly 3-fold increase in HIV (OR=2.74, 95\% (CI): 1.41, 5.31).

- Increasing age at entry into prostitution slight decrease in odds of HIV but non-significant after adjustment (for 1-year increase in age, $\mathrm{OR}=0.97,95 \%$ CI: 0.91, 1.02).

- Significant heterogeneity in association between forced entry into prostitution and HIV according to recent history of sexual violence (Wald $\mathrm{P}$ for interaction $=0.01$ ).

- In presence of recent sexual violence, forced prostitution increased the odds of being HIV- infected 11-fold (OR=11.13, 95\% CI: 2.41 , 51.40).

- No evidence for a direct effect of forced prostitution on HIV infection in the absence of recent sexual violence $(\mathrm{OR}=1.79,95 \%$ CI: $0.74,4.31)$.

- Recent sexual violence did not modify the relationship between age at entry into prostitution and HIV infection (Wald $\mathrm{P}$ for interaction $=0.41$ ).

Zimmerman et al., - 59\% reported pre-trafficking experiences of sexual or physical 2008 violence, $12 \%$ had a forces or coerced sexual experience before age 15

- $26 \%$ reported more than 1 perpetrator especially father or stepfather

- $95 \%$ reported physical or sexual violence whilst being trafficked

- $76 \%$ reported sexual abuse, $57 \%$ reported physical injuries

- $76 \%$ were restricted in travel or being 'able' to do as they wish

- Physical symptoms: headaches (82\%), easily tired (81\%), dizziness (70\%), pain (back 69\%; stomach 61\%; pelvic 59\%), memory difficulty (62\%), gynaecological infections (58\%).

- $63 \%$ had $10+$ concurrent physical health problems

- Mean scores for symptoms of depression, anxiety, hostility 2.09, 1.90, and 1.21, respectively, using Brief Symptom Inventory subscales.

- Symptoms depression 39\% suicidal thoughts in past 7 days; $57 \%$ PTSD.

\section{DISCUSSION}

The devastating effect of sex trafficking on physical, mental and social wellbeing, especially on women and children, make this a key health issue as well as a human rights one ${ }^{24-27}$. Physical violence, unsafe sexual practices, brutal working and living conditions, poor access to health services result in a reduced health status of trafficked women and children. There are multiple health risks associated with trafficking, with consequences often overlapping and intertwining. Trafficked persons are abused physically, emotionally and mentally and such experiences can have long-term effects on victims' health. The most prevailing physical health issues for which trafficked women sought help for in the included studies ranged from neurological exertions, like headaches, dizzy spells, or memory loss, to gynaecological 
problems like lower abdominal pain; symptoms like fatigue, loss of appetite, weight loss; persistent back pain, to specific infectious diseases like STIs, HIV and tuberculosis coinfection. The physical health risks negatively affect the mental health of the victims as well.

The review identified significantly higher proportion of sex-trafficked women and girls tested positive for HIV infection. This finding is consistent with the finding of high of HIV in Burmese Shan women and young girls trafficked to brothels in Thailand ${ }^{28}$.

Sex trafficking adds to the pandemic heterosexual spread of HIV. Moreover, the studies included in this review suggested that younger girls who were trafficked at the age of 14 years or even younger were more likely to have contracted HIV infection than those trafficked at a (slightly) older age. The younger girls are vulnerable in multiple ways. Foremost, their biological vulnerability due to larger areas of cervical ectopy attributable to repeated sexual trauma to an immature genital tract during sexual intercourse may be a factor contributing to the increased risk for HIV infection and other STIs among younger girls ${ }^{22,29}$. The increased vascularity of the immature cervix in younger girls is also prone to contract Human Papilloma Virus (HPV) infection which may finally lead to cervical cancer. Younger girls are preferred by male brothel clients due to the persisting myth that sex with young girls and virgins are a remedy for HIV/AIDS ${ }^{30}$.

At the same time, younger girls often possess inadequate information on the infectious nature of STIs and HIV, the concept of safe sex (with condom use) or are unable to negotiate condom use due to language barriers and threats from the brothel owners, all this makes them increasingly vulnerability to HIV and other infections ${ }^{22,28,30-32}$. It seems younger girls are not only more susceptible and easier victims to the traffickers generating more income but they are also a more vulnerable group in terms of health risks. Considering all these circumstances, increased efforts and programmes should be offered to prevent sex trafficking in younger girls, for the victims themselves but also for the benefit of the wider public health. In addition there is a need for more pro-active rescue operations of women from brothels of those already trafficked.

Apart from identifying life-threatening diseases among sex-trafficked population, the studies highlight violence as a measure for enforced conversion of innocent victims into sex workers and continuous violence to maintain control over victims during their confinement in brothels $3,8,33,34$. They were also coerced to use contraceptives and endured forced abortions. There is evidence that the victims were not given proper care or taken to appropriate health care services for treatment during the forced sexual servitude, irrespective of their illness or injuries. Often they were forced to continue their work when ill. Due to lack of treatment on time, the curable symptoms of STIs such as Gonorrhoea and Chlamydia are left untreated potentially leading to PID with further complication such as chronic pelvic pain, ectopic pregnancy and infertility ${ }^{4}$.

Trafficked women and girls also face severe psychological trauma once entrapped in the criminal world of sex trafficking $8,12,34$. Already shattered with pre-trafficking brutal experiences, the victims' mental health further deteriorates with continuous violence and mental and physical torture in the brothels ${ }^{11}$. To cope with the extreme stress, the victims adapt different coping mechanisms such as smoking and drinking which can become an addiction ${ }^{11}$. The vulnerability of getting tuberculosis in sex-trafficked women and girls ${ }^{20}$ can also be described by these risk-taking behaviours either in the form of forced or voluntary consumption of drugs, alcohol and tobacco. Moreover, the substance use may intensify the risk of HIV infection among the victims of sex trafficking ${ }^{11}$. 
Trafficked women and children may suffer from a range of mental health disorders varying from hopelessness, difficulty in sleeping, fearfulness, self-guilt and low self-esteem, lack of motivation, aggression and anger, altered behaviour in front of males, anxiety, sometimes as severe as PTSD, depression with suicidal thoughts and even suicidal attempts ${ }^{3,8,33-34}$. The review has identified severe depression, anxiety and PTSD as the most prominent mental health disorders suffered by the victims of sex trafficking. One of the studies reports depression to be higher among sex-trafficked females than those trafficked for other non-sexual work ${ }^{19}$. It is worth highlighting that the psychological trauma persists among the victims even after being taken out of the threatening environment. Consequently, the rehabilitation centres should provide extensive counselling and behavioural therapies in addition to the physical rehabilitation to boost their self-esteem and regain their confidence and provide continue professional help and support to overcome the situation.

\section{STRENGTHS \& LIMITATIONS:}

This review carried out a systematic search to identify all the relevant papers that explored the health risks and consequences of sex trafficking among women and children. Four large bibliographical databases, Medline, EMBASE, PSYCINFO and CINAHL were searched to identify relevant papers with additional searching of references, without geographical restrictions. This review is up-to-date until June 2016 and therefore also includes the citation search studies. This review could not perform a meta-analysis because of the heterogeneity of the data (derived from mixed-methods).

The word "prostitution" had to be deleted in the search strategy as it generated enormous number of additional irrelevant articles that addressed non-trafficked population. Consequently it is possible that some relevant articles may have been missed. Moreover, the population in most of the included studies were trafficked females and children who were rescued and at the time residing in the rehabilitation homes or shelters run by NGOs, so the health consequences and experiences reported might differ from those trafficked but not rescued. Also the use of case notes and medical records in majority of the studies might be prone to errors by the case recorders and likely to have recall bias by the trafficking survivors. Nevertheless, the implications can be taken into consideration for planning preventive activities against sex trafficking for this vulnerable group; strengthening the knowledge about migration, and increasing awareness about trafficking and its consequences in the most affected areas; and giving more emphasis on the care, reintegration and rehabilitation of victims going through the gravest consequences of sex trafficking. The search strategy did not include hand-searching of selected journals and excluded non-peer reviewed literature.

\section{CONCLUSION}

Trafficking in persons is a very complex and multi-causal phenomenon that predominantly affects women and children and is increasingly recognised as a global public health problem. The practices of women and child trafficking place the victims at extreme risk of physical danger, psychological trauma, depression, sexual abuse, STIs including HIV. Most studies in this review focussed on the physical health problems of the trafficked victims although a large mental health burden exists in the post trafficking life of the victims. Even after release from the sexual servitude, the higher level of psychological problems can be attributable to the development of lack of resilience and poor mental functioning during their time in the brothel. Subsequently, this problem may affect a quick recuperation and early reintegration of these victims into their original community. Key policy makers, government officials, public health 
officials, health care providers, legal authorities and NGOs should be made aware about the health risks and consequences of trafficking. Trafficking consequences should be recognised as a public health issue and all the related sectors including regulating bodies should coordinate their efforts to fight against sex trafficking. Further research is also needed to identify the similarity and differences between health risk and problems faced by trafficked and nontrafficked women and girls in different settings.

\section{COMPETING INTERESTS}

The authors declare that they have no competing interests

\section{FUNDING}

This study had financial support from Liverpool John Moores University and Bournemouth University. The funders had no role in study design, data collection and analysis, decision to publish, or preparation of the manuscript.

\section{AUTHORS' CONTRIBUTIONS}

PS and EvT developed the review protocol. AP and AS contributed to the searching and search strategy. All authors assisted in the interpretation of data, commented on drafts and approved the final submission.

\section{REFERENCES}

1. The Senate and House of Representative. Victims of trafficking and violence protection act of 2000. The United States Department of States. Washington DC: 1470.

2. United Nations Office on Drugs and Crime. Trafficking in persons: global patterns. United Nations Office on Drugs and Crime. Vienna; 2006.

3. Raymond JG, DCunha J, Dzuhayatin SR, Hynes HP, Rodriguez R. A comparative study of women trafficked in the migration process. Patterns profiles and health consequences of sexual exploitation in five countries (Indonesia the Philippines Thailand Venezuela and the United States), 2002.

4. Abdulraheem S, Oladipo AR. Trafficking in women and children: a hidden health and social problem in Nigeria. Int J Sociol Anthropol. 2010;2 (3):34-39.

5. Beyrer C, Stachowiak J. Health consequences of trafficking of women and girls in Southeast Asia. Brown J World Affairs. 2003; 10:105.

6. Zimmerman C, Hossain M, Yun K, Roche B, Morison L, Watts C. Stolen smiles: a summary report on the physical and psychological health consequences of women and adolescents trafficked in Europe. London School of Hygiene \& Tropical Medicine (LSHTM), London, 2006. http://www.lshtm.ac.uk/php/ghd/docs/stolensmiles.pdf .

7. Raymond JG. Health effects of prostitution. In: Hughes DM, Roche C (Eds). Making the Harm Visible. The Global Sexual Exploitation of Women and Girls Speaking out and Providing Services. Coalition against Trafficking in Women, New York, 1999.

8. Zimmerman C, Yun K, Shvab I, Watts C, Trappolin L, et al. The health risks and consequences of trafficking in women and adolescents. Findings from a European study. London: London School of Hygiene \& Tropical Medicine (LSHTM), 2003. http://www.lshtm.ac.uk/php/ghd/docs/traffickingfinal.pdf. 
9. Richardson R NHS Centre for Reviews and Dissemination [Internet]. Guidelines in practice. $2000 . \quad$ Available from: https://www.guidelinesinpractice.co.uk/dec_00_richardson_keyorgs-dec00

10. Silverman JG, Decker MR, Gupta J, Maheshwari A, Willis BM, Raj A. HIV prevalence $\&$ predictors of infection in sex-trafficked Nepalese girls \& women. JAMA. 2007;298(5):536-542.

11. Gupta J, Raj A, Decker MR, Reed E, Silverman JG. HIV vulnerabilities of sex-trafficked Indian women and girls. Int J Gynaecol Obstetr. 2009;107(1):30-34.

12. Zimmerman C, Hossain M, Yun K, Gajdadziev V, Guzun N, et al. The health of trafficked women: a survey of women entering posttrafficking services in Europe. Am J Public Health. 2008; 98(1):55-59.

13. Oram S, Ostrovschi NV, Gorceag VI, Hotineanu MA, Gorceag L, et al. Physical health symptoms reported by trafficked women receiving post-trafficking support in Moldova: prevalence, severity and associated factors. BMC Womens Health. 2012; 12(1):20.

14. Abas M, Ostrovschi NV, Prince M, Gorceag VI, Trigub C et al. Risk factors for mental disorders in women survivors of human trafficking: a historical cohort study. BMC Psychiatry. 2013; 13(1): 204.

15. Silverman JG, Raj A, Cheng DM, Decker MR, Coleman S, et al. Sex trafficking and initiation-related violence, alcohol use, and HIV risk among HIV-infected female sex workers in Mumbai, India. J Infect Dis. 2011; 204 (5): 1229-1234.

16. Decker MR, McCauley HL, Phuengsamran D, Janyam S, Silverman JG. Sex trafficking, sexual risk, sexually transmitted infection and reproductive health among female sex workers in Thailand. J Epidemiol Community Health. 2010; 65(4): 334-339.

17. Sarkar K, Bal B, Mukherjee R, Chakraborty S, Saha S, Ghosh A, et al. Sex-trafficking, violence, negotiating skill, and HIV infection in brothel-based sex workers of eastern India, adjoining Nepal, Bhutan, and Bangladesh. J Health Popul Nutr. $2008 ; 26$ (2):223.

18. George A, Sabarwal S. Sex trafficking, sexual and physical violence, and HIV risk among young female sex workers in Andhra Pradesh, India. Int J Gynecol Obstetr; 2013;120: 119-123.

19. Tsutsumi A, Izutsu T, Poudyal AK, Kato S, Marui E. Mental health of female survivors of human trafficking in Nepal. Soc Sci Med 2008; 66(8): 1841-1847.

20. Dharmadhikari AS, Gupta J, Decker MR, Raj A, Silverman JG. Tuberculosis and HIV: a global menace exacerbated via sex trafficking. Int J Infect Dis. 2009; 13(5):543-546.

21. Gupta J, Reed E, Kershaw T, Blankenship KM. History of sex trafficking, recent experiences of violence, and HIV vulnerability among female sex workers in coastal Andhra Pradesh, India. Int J Gynecol Obstet. 2011;144(2): 101-105.

22. Silverman JG, Decker MR, Gupta J, Maheshwari A, Patel V, et al. HIV prevalence and predictors among rescued sex-trafficked women \& girls in Mumbai, India. J Acquir Defic Syndr. 2006;43(5): 588-593.

23. Wirth KE, Tchetgen Tchetgen EJ, Silverman JG, Murray MB. How does sex trafficking increase the risk of HIV infection? An observational study from Southern India. Am J Epidemiol. 2013; 177 (3): 232-241. 
24. Zimmerman C, Watts C. Risks and responsibilities: Guidelines for interviewing trafficked women. Lancet. 2004;363(9408):565.

25. Beyrer C. Is trafficking a health issue? Lancet. 2004;363(9408):564.

26. Family Violence Prevention Fund. Turning pain into power: trafficking survivors' perspectives on early intervention strategies. Family Violence Prevention Fund, San Francisco, 2005.

27. Gushulak BD, MacPherson DW. Health issues associated with the smuggling and trafficking of migrants. J Immigr Health. 2000; 2(2): 67-78.

28. Beyrer C. Shan women and girls and the sex industry in Southeast Asia; political causes and human rights implications. Soc Sci Med. 2001; 53(4):543-550.

29. Sarkar K, Bal B, Mukherjee R, Saha MK, Chakraborty S, Niyogi SK, et al. Young age is a risk factor for HIV among female sex workers - an experience from India. J Infect. 2006; 53(4):255-259.

30. Nair PM. A report on trafficking in women and children in India 2002-2003. NHRC and UNIFEM ISS project, New Delhi, 2002. Available from: http://nhrc.nic.in/Documents/ReportonTrafficking. pdf. Accessed July 2016.

31. Willis BM, Levy BS. Child prostitution: global health burden, research needs, and interventions. Lancet. 2002; 1417-1422.

32. Poudel P, Carryer J. Girl-trafficking, HIV/AIDS, and the position of women in Nepal. Gender Develop. 2000; 8(2):74-79.

33. Raymond JG, Hughes DM, Gomez CJ (2001) Sex trafficking of women in the United States: Internatonal and domestic trends. Coalition against Trafficking in Women, Amherst Available from : http://www.uri.edu/artsci/wms/hughes/sex_traff_us.pdf Accessed May 2016.

34. Cwikel J, Ilan K, Chudakov B. Women brothel workers and occupational health risks. $J$ Epidemiol Community Health 2003; 57(10): 809-815. 
This page is intentionally blank 